\section{Chitja Twala}

Senior Lecturer and Head of Department, Department of History, University of the Free State. E-mail: twalacm@ ufs.ac.za

DOI: https://dx.doi. org/10.18820/24150509/ JCH43.v1.7

ISSN 0258-2422 (Print) ISSN 2415-0509 (Online)

Journal for Contemporary History

2018 43(1):137-159

(C) UV/UFS

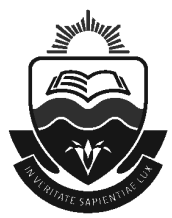

STUDENT ACTIVISM AND CONTESTATION FOR POLITICAL SPACE AT THE FORMER UNIVERSITY OF THE NORTH (QWAQWA BRANCH), 1986-1996

\section{Abstract}

The history of student activism and contestation for political space as exhibited by the student organisations at one of the former University of the North's (Turfloop) satellite campus or branch, UNIQWA, remains untold and scarcely documented, despite the available evidence that UNIQWA experienced student protests between the mid-1980s and mid-1990s. There were occasions whereby student political activists and their organisations were depicted as a united core, despite their political affiliations. However, at some point the underlying ideological differences took centre stage in the contest for political space on campus. This article attempts to highlight the role played by UNIQWA student formations and their contestation for political space, and the impact this had on the advancement of the liberation cause.

Keywords: Student activism; University of the North; Turfloop; UNIQWA; ideological differences; liberation; Azanian People's Organisation; political activists; student politics.

Sleutelwoorde: Studente-aktivisme; Universiteit van die Noorde; Turfloop; UNIQWA; ideologiese verskille; bevryding; Azanian People's Organisation; politieke aktiviste; student-politiek.

\section{INTRODUCTION}

The decade of the 1980s was viewed as a period of ungovernability in South Africa (SA). This was in response to the clarion call made by the President of the African National Congress (ANC), Oliver Tambo, while in exile to render SA ungovernable. The youth and student organisations heeded the call by Tambo. The formation in 1983 of the United Democratic Front (UDF) ${ }^{1}$ and later

1 On the formation of and what the UDF stood for, see University of the Witwatersrand, William Cullen Library, Department of Historical Papers, AK 2117-J4-22-AAX8-001, "Trade Unions and the UDF", pp. 1-12; University of the Witwatersrand, William Cullen Library, Department of Historical Papers, AK 
structures, such as student organisations, initiated the socio-educational reforms within the country. Therefore, Qwaqwa was not spared in the political revolution that engulfed the country.

This article refers to the points of contact and contestation for political space within the student organisations at UNIQWA ${ }^{2}$ during the period under discussion. In spite of the political affiliations, it is argued in this article that student organisations on the UNIQWA campus were not isolated from the political mass mobilisation that was happening outside Qwaqwa. This was demonstrated in many of the influences and campaigns embarked upon during the period under discussion. The following key questions will be addressed: How did the nation-wide political developments influence students' activism at UNIQWA? Did students' political affiliations contribute to confrontations and conflicts amongst the student community at UNIQWA? Did nation-wide politics manage to stand above student politics at UNIQWA in pursuit of the national struggle for liberation?

In search of answers to the above-mentioned questions, the article shows that, in one way or another, students' political differences had negative consequences for the speedy attainment of the anticipated freedom. Political differences at UNIQWA were a manifestation of the country's student politics. Therefore, this article is situated in a broader scholarship on students' political activism in SA. Furthermore, it should be noted that the so-called agents of the apartheid regime had limited success in dealing with student protests across the country, including Qwaqwa. Equally, the regime could not comprehend the tendencies of manipulation of student politics by the liberation movements. Ultimately, university managements failed to address students' demands. On many occasions these demands were linked to the national socio-political demands experienced by the black majority in SA. ${ }^{3}$ The research in this article

2117-J4-22-AAX12-001, "Declaration of the United Democratic Front", pp. 1-2. For more information on the UDF, see J Seekings, UDF: History of the United Democratic Front in South Africa 1983-1991 (Athens, Ohio: Ohio University Press, 2000); GF Houston, The national liberation struggle in South Africa: A case study of the United Democratic Front, 1983-1987 (Ashgate: Aldershot, 1999); I van Kessel, Beyond our wildest dreams: The United Democratic Front and the transformation of South Africa (Charlottesville: University Press of Virginia, 2000).

2 It should be noted that, although the name UNIQWA was used in general reference to the Qwaqwa Campus of the University of the North (Turfloop), this was not officially adopted by either the management of Turfloop or of Qwaqwa Campus.

3 From 1978 to 1983, black universities experienced a political lull and quiescence. The imprisonment of SASO's leading members in 1976, and its banning the following year, created a leadership vacuum at black campuses that proved difficult to fill. For example, the Turfloop management banned SASO for sparking unrest on the campus, which later spread to other black campuses. When lectures resumed in 1978, the University's management was vigilant in screening students considered for readmission. The universities of Fort Hare and Zululand were equally hostile to student political activism when they reopened in 1978. At the University of Zululand, management suspended the $\mathrm{SRC}$ for fear that it would resume political mobilisation and organisation of students. 
covers, among other things, the period 1986 to 1996 for the following main reasons: some students who became activists at UNIQWA, came from the ranks of the student organisations which operated under the banner of the UDF; it was in the mid-1980s that UNIQWA demanded properly constituted SRC structures; it was the period when contestation for political space manifested within the student organisations and more student/political campaigns were embarked upon at UNIQWA than in all other years; it was during this period that some students became politically conscious and became excited with new exposure; and an alignment to broad national political issues took centre stage in campus politics.

The article also adds to previous research conducted on student political activism in SA and elsewhere on the continent. ${ }^{4}$ However, more emphasis is placed on the neglected role played by UNIQWA students during the period under discussion. The use of oral testimonies in the documenting of SA's liberation history has proved to be important. It enables the interviewees to reflect on their experiences and close the gaps left open by written sources. Through this methodology, the researcher has been able to tap into the memories of the role players who were directly, or indirectly, involved at UNIQWA; something that is mostly neglected by historians in the documenting of student activism histories. Despite the use of secondary sources in the form of published books, chapters in books and journal articles, oral testimonies have been used alongside archival research, because all these complement one another; thus enabling a balanced approach to the history of student activism at UNIQWA.

One of the central arguments in this article is that dominant ways of thinking about student political activism and contestation for political space have been complicit with the construction of a resistance attitude outside university campuses. These dynamics have frequently been neglected when writing about student politics. It should also be noted that in this article, the researcher consciously avoided using the term "ideological differences of student organisations" for the following two reasons: In most cases the term "ideology" in a political context can imply an element of social determination, and not social determinism. Following the Marxist school of thought, it is viewed as a rationale or rationalisation for ruling class domination, which in one way or the other may be interpreted as false consciousness by the dominated.

4 Other works published on student political activism in South Africa and elsewhere on the continent included, but are not limited to the following: T Muswede, "Colonial legacies and the decolonization discourse in post-apartheid South Africa: A reflective analysis of student activism in Higher Education", African Journal of Public Affairs 9(5), January 2017, pp. 201-210; C Koen, M Cele and A Libhahber, "Student activism and student exclusions in South Africa", International Journal of Education Development 26, 2006, pp. 404-414; A Keet, "Conceptual challenges and practical concerns: Education as a human right and education as a public good", Quarterly Review of Education and Training 12(1), 2005, pp. 5-9; A Heffernan, "The University of the North and building the Bantustans, 1959-1977", South African Historical Journal 69(2), pp. 195-214; AS Mlambo, "Student activism in a time - Zimbabwe 2000-2010: A tentative exploration”, Journal for Contemporary History 38(1), June 2013, pp. 184-204. 


\section{LITERATURE REVIEW}

Most of the literature on student political activism in SA typically follows a similar pattern; that of providing an etymological interpretation of students' political consciousness over time. However, this approach neglects the generational and political influences of such political activism. Consequently, few sources use the narratives and oral testimonies of those who were involved. Furthermore, the existing literature fails to highlight the synergy between the university as a community institution and the community demands and expectations thereof.

The point of departure is recognition of the fact that, what may be labelled as student activism covers a very wide and diverse range of experiences and processes of influences that are sometimes excluded if one only considers educational issues. The diversity in political experiences of students also suggests that generalisation about student activism may pose analytical challenges, especially in the SA context. Conceptually, one crucial aspect of student activism has to do with structural and educational inequalities and the power struggles these give rise to. In many situations, student groups are mobilised because of exclusions by the institutions of higher learning on decision-making processes.

The period of the late 1970 s and early 1980 s saw many historians starting to situate students' plight in the broader context of the struggle for liberation in SA. Although this gained more prominence in the historiography of the struggle for liberation from the mid-1980s, there was a limited attempt to explore the intricacies involved in such organisation's contest for political space, particularly at UNIQWA. For example, the work by S Mathabatha entitled, The 1976 student revolts in the schools in Lebowa, 1970-1976, is a case in point. He describes student politics in the former homeland of Lebowa. ${ }^{5}$ The strength of the article lies in relating the school uprising in Lebowa with the political developments that were taking place at some of the country's universities. This was evident when Mathabatha stated, "This article focuses on the development of political youth culture in missionary, former missionary and specialised schools within the homeland of Lebowa, which began with the imposition of Afrikaans as a medium of instruction. It argues that the selective imposition of Afrikaans on some Lebowa schools by the apartheid government from 1974 engendered patterns of resistance similar to those that took place in Soweto schools during the 1976

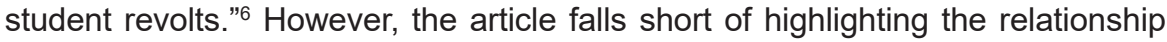
of high school students with those at the universities outside Lebowa and the possible political similarities or differences, if any. This was an indication that a

5 S Mathabatha, "The 1976 student revolts and the schools in Lebowa, 1970-1976", South African Historical Journal 51(1), 2004, pp. 108-129.

6 Ibid. 
lot has been written about the history of student activism in other homelands of the same status as Qwaqwa.

However, publications on student protest and activism in SA and beyond the country's borders have broadened the interpretation of student political developments at UNIQWA and elsewhere within the country. One helpful source was the work of VP Franklin on patterns of student activism and the investigation of similarities of student political activism in the United States (US) and SA. The researcher argues that such an investigation will assist in tapping in on the lessons learnt from such countries. Interestingly, Franklin also writes about the different encounters of student activism in both countries. ${ }^{7}$

Another important source is S Badat's work. He provides an impressive history of student crises, as well as politics, in South Africa. Furthermore, he alludes to the active role organisations played in the quest for political liberation in SA. His approach of complementing the South African Students' Organisation (SASO) and the South African National Students Congress (SANSCO) as revolutionary national student organisations is commendable. ${ }^{8}$ Although the information provided in Badat's work was known, he managed to present it in a narrative way, showing all the contradictions in as far as the ideological stance of the student formations was concerned.

In a recently completed $\mathrm{PhD}$ study, $\mathrm{M}$ Dominick makes a significant contribution to this historiography and to an understanding of student politics by comparing four selected universities, two in SA (the Universities of Zululand and Pretoria) and the other two in Tanzania (the Universities of Dar-es-Salaam and Dodoma). Although his emphasis is on the consolidation of democracies, the study also provides an insight into the situation before democratisation. ${ }^{9}$ Another similar study for a MEd was undertaken by AM Mwollo-Ntallima, focusing on student political activism in Tanzania. He outlines, "the demand for democracy on the African continent was actually born from the womb of student activism in the early 1970s. Several student activists and organizations targeted the one party system and/or authoritarian regime and their associated consequences in African society." ${ }^{0}$ The information provided above clearly shows that the question of student activism was not unique to SA. His analysis is powerful and

$7 \quad$ VP Franklin, "Patterns of student activism at Historically Black Universities in the United States and South Africa, 1960-1977", The Journal of African American History 88(2), Spring 2003, pp. 204-217.

8 MS Badat, Black student politics, Higher Education and apartheid from SASO to SANCO, 1968-1990 (Pretoria: HSRC, 1999).

9 M Dominick, The nexus between national and student politics: Managing student conflicts in four African Universities in an era of democratic transition (PhD, University of Zululand, 2014).

10 AM Mwello-Ntallima, Higher Education and democracy: A study of students' and student leaders' attitudes towards democracy in Tanzania (MEd, University of the Western Cape, 2011), p. 17. 
apparently persuasive. Several issues or indicators are highlighted to explain the relations between the student organisations and the national political parties. One also tends to agree with $\mathrm{R}$ Mattes and $\mathrm{M}$ Bratton who argue that, in most cases, democratic awareness by students contributed to their political activism. ${ }^{11}$ The same could also be said about UNIQWA students who were politically aware of the developments unfolding in SA in the mid-1980s.

In 2007, a 119-page document entitled From UNIN to UFS - 25 years was published as a jubilee document chronicling the history of UNIQWA. The document intended highlighting UNIQWA's achievements since its establishment in 1982. Although no in-depth analysis is provided, the document, compiled by R Moffett of UNIQWA and his committee, succeeded in recording snippets on the history of the institution and some activities by students. ${ }^{12}$ Equally, an MA dissertation completed by S Semela on the history of the institution lacks an in-depth analysis of the activities and the role students played in as far as the political politicisation was concerned. ${ }^{13}$ Despite these shortcomings, both documents provided some valuable information for the purpose of this article.

\section{THE RATIONALE TOWARDS THE ESTABLISHMENT OF UNIQWA IN 1982}

According to AL Mawasha, as early as 11 October 1956, the idea of establishing agricultural colleges for the northern and western regions, as well as Witsieshoek, was discussed by traditional leaders. All 14 traditional leaders agreed that the National Party's (NP's) Government was to be approached in facilitating this. Chief Paulus Mopeli, on behalf of Qwaqwa, pleaded for the establishment of an agricultural college in his area. It was not known to these traditional leaders at that stage that this would culminate in the establishment of branch campuses. To the NP Government, this would enforce its idea of "separate development" as envisaged in the Group Areas Act of $1950 .{ }^{14}$

The above was an indication that the Qwaqwa Government's foundation laid on the promotion of education. This was evident also in the mushrooming of schools, from primary to secondary, including colleges of education in the area. The Qwaqwa Government made concerted efforts to establish UNIQWA in order to serve the needs of the Qwaqwa people, as well as the surrounding

11 R Mattes and M Bratton, "Learning about democracy in Africa: Awareness, performance, and experience", American Journal of Political Science 51(1), 2007, p. 200.

12 R Moffett, From UNIN to UFS - 25 years: A history of the Qwaqwa Campus of the University of the Free State (Bloemfontein: University of the Free State, 2013).

13 MS Semela, The development and role of the Qwaqwa Campus of the University of the North, 1982-1998: A historical case study (MA, University of the Free State, 1999).

14 AL Mawasha, "Turfloop: Where an idea was expressed, hijacked and redeemed". In: M Nkomo, D Swartz and B Maja (eds), Within the realm of possibility: From disadvantage to development at the University of the North (Cape Town: HSRC, 2006), p. 65. 
areas. Unfortunately, the university that was established in Qwaqwa was not what the homeland government had envisaged. The aspirations of the Qwaqwa Government were to establish a polytechnic institution which would offer practice-oriented courses. The first Director/Principal appointed at the newly established institution was W Modinger. Although he was recruited from the University of the Transkei, where he served as Dean of the Faculty of Science, he was originally from Germany. With his German origins, it was hoped that he would steer UNIQWA into being a polytechnic institution, as such institutions existed in Germany.

Turfloop curriculum was practice-oriented and not what the Qwaqwa Government had envisaged. When the institution started, it focused mainly on Education students. Mathene Mahanke, one of the first black lecturers at UNIQWA when it was established, apportioned the failure of having UNIQWA as a polytechnic institution primarily to the model of Turfloop's curriculum. One other motive was that UNIQWA targeted teachers who were already teaching with the single purpose of improving their qualifications; hence the lectures were conducted in the evenings, except for a few who were doing sciences, such as chemistry and zoology with experiments and practicals. ${ }^{15}$

When UNIQWA was established, there had been an agreement of accreditation between the Witsieshoek Theological School and the University of Zululand. The purpose of this agreement was to provide the students of the School with the necessary qualifications, to be accepted as part of the Faculty of Theology of the University of Zululand. Therefore, the accreditation process ended when Turfloop took over and established UNIQWA.

The dilemma with the establishment of institutions, such as UNIQWA, and of which students were critical, was that it created an opportunity for the appointment of white Afrikaner academics, many of whom could not be absorbed into white institutions. Inevitably, as argued by one of the mid-1980's students activist, Sibusiso Sithole, these academics, who were mainly Afrikaans speaking, approached the curriculum from an Afrikaner perspective and, in some instances, found it difficult to express themselves in English. Many students viewed this as the continuous perpetuation of Afrikanerdom ideals. Therefore, UNIQWA became no different from other established black universities around the country. ${ }^{16}$ The students accused some of these lecturers of being members of the Broederbond. ${ }^{17}$ Flimsy excuses were provided that there were not

15 Twala Personal Collection (TPC). E-mail correspondence with $\mathrm{Dr} M$ Mahanke, 26 October 2015.

16 TPC. Interview with Mr S Sithole, conducted by C Twala, Intabazwe Township, Harrismith, 16 June 2011.

17 The Afrikaner Broederbond was loosely translated as "League of Afrikaner Brothers". It was an organisation formed in June 1918. Initially, it was called "Jong Suid-Afrika", but it changed its name to "Afrikaner Broederbond" in 1919. It was a secret Afrikaner organisation. Broederbonders in the civil service and armed forces, in the teaching corps 
enough black academics to teach at UNIQWA. The researcher argues that the employment of white Afrikaans-speaking academics was tantamount to shortchanging black students with the depth and quality of training required for the degrees. In one way, or the other, their approach compromised the academic project of UNIQWA, which the students rigorously challenged at various levels, among other by the use of cartoons. These cartoons were distributed around midnight or early hours of the morning, as some lecturers had their informants among the student body.

Moffett highlighted the fact that there were also problems with the recruitment of staff. In 1981 when the nine academic posts were advertised, not all of them were filled. Finding suitable candidates who were prepared to work in rural Qwaqwa became an on-going problem. In the main, the problems were complicated by the following: Firstly, there were very few black people qualified to teach at universities. Secondly, there was no accommodation for whites in Qwaqwa; therefore, they had to commute between Harrismith or Bethlehem to Qwaqwa. Thirdly, when the University was established, it was accommodated at Lere la Tshepe, that was $65 \mathrm{~km}$ from Harrismith and $80 \mathrm{~km}$ from Bethlehem. ${ }^{18}$ With the establishment of UNIQWA, the Theological College staff was also absorbed and that contributed to students' numbers and staff. ${ }^{19}$

From the above, it is clear that the establishment of branch campuses was no mean task. It was a complex exercise, in view of the fragile political climate

and professions, were committed to advancing the interests of "Afrikanerdom" which was defined by the exclusion of others, of English-speakers and anyone who was not perceived to be white. They were against the conciliatory attitude of Smuts and Botha's politics, with an emphasis on building a sense of a shared South African nation among Afrikaans and English-speaking people. For more information on the interpretation of the role of the Broederbond in education, see M Morris, Every step of the way: The journey to freedom in South Africa (Cape Town: HSRC, 2005), p. 159; NG Radebe, Post-apartheid education resistance in black secondary schools in the Goldfields, (PhD, Vista University, 2000), p. 18; EG Malherbe, Education in South Africa, (Cape Town: Juta and Co, 1977), p. 23; MS Rakometsi, The transformation of black school education in South Africa, 1950-1994: A historical perspective (PhD, University of the Free State, 2008), pp. 39-40. Moffett, p. 17.

19 The following were members of staff when UNIQWA started and two years later: Director: Prof. W Modinger; Acting Registrar: Mr HS Mokone (secondment from Turfloop); Typist: Mrs JS Steyn; Theology: Dr DR de Villiers; Education: Prof. SS Rapinga and WC Niewoudt and Mr TI Makume; Political Science: Prof. LJ Ferreira; Business Economics: Mr LJG Jonker; Public Administration: Mr HH van Gass; Afrikaans: Mr IFW Steyn; South Sotho: Mr MA Mahanke; Classical Languages: Mr JR Louw; Sociology: Mr DS van der Merwe; Geography: Mr EN Mullins; History: Dr CJP le Roux (started second semester); Psychology: Mr HA Raath (started second semester); Botany: Mr WJ Jankowitz (lectures started in 1983); Zoology: Prof. J den Heyer (lectures started in 1983); Dogmatics: Prof. DR de Villiers; Old Testament: Rev'd W de W van Velden; New Testament: Rev'd SP Botha; Church History: Rev'd JM May; Diaconology (Practical Theology): Rev'd JB Veitch; Diaconology: Rev'd ES Nchephe; and Missiology: Dr AA Odendaal jnr. See Moffett, pp. 19-20. 
of the 1980s in South Africa. Drawing from the experiences of other African countries, I Munene, using the case of Kenya, argues that branch campuses brought forward three models of university systems, namely: high-autonomy, mid-autonomy, and low-autonomy campuses. The latter had the least decisionmaking powers over administration, financial and academic issues. All these remain constituents of the main campuses. ${ }^{20}$ UNIQWA fitted the last description model with all the challenges it experienced. Evidently, the budget was determined by Turfloop, including the awarding of degree certificates. Tshepo Mashiloane had the following to say, "UNIQWA was helpful to the low-income parents who wanted to send their children to a university. The fees were relatively lower. However, this exposed the University in admitting none deserving students into its fold. The University mainly survived on the fees charged [...] Depending on Turfloop for academic guidance was also a challenge. Structurally UNIQWA produced mainly undergraduate students with little success at post-graduate level. We were fully aware that all initiatives for programmes came from Turfloop. This arrangement itself subjected us to second-class type of students [...] I was equally shocked to learn that when UNIQWA started, some of the lecturers would come from Turfloop and have blocked classes here in Qwaqwa."21

\section{STUDENT ACTIVISM WITHIN THE BROADER SOUTH AFRICAN CONTEXT}

In the 1970s, students were politically active in SA. The formation of the Black Consciousness (BC) movement aligned SASO escalated students' activism to a higher level. The level of students' political consciousness was also strengthened. ${ }^{22}$ SASO's mission was to expose the needs and aspirations of black students. Furthermore, it wanted to establish the identity of the blacks through which they could find fulfilment in their being, and recognise their identity as being distinct and unique. ${ }^{23}$

The Congress of South African Students (COSAS), formed in 1979 by the former South African Students' Movement (SASM) activists, became the first

20 See II Munene, Multi-campus university systems: Africa and the Kenyan experience (New York: Routledge, 2001), p. 125.

21 TPC. Interview with Mr T Mashiloane, conducted by C Twala, Intabazwe Township, Harrismith, 16 June 2011.

22 University of the Witwatersrand, William Cullen Library, Department of Historical Papers, AD 2189-A5-01, "South African Students Organization (SASO), 1969-1973: SASO historical background", pp. 1-3.

23 University of the Witwatersrand, William Cullen Library, Department of Historical Papers, AD 2189-B1-01, "South African Students Organization (SASO), 1969-1973: Students, politics; Black Power, new movement and new approvals", p. 2. For more information on the formation of SASO, see CRD Halisi, Black political thought in the making of South African democracy, (Bloomington: Indiana University Press, 1999), pp. 104-106. 
new Charterist student organisation emerging in the aftermath of the 1976-1977 uprisings. COSAS branches provided an organisational home to many nonstudent youths until 1982, when the organisation decided to limit its membership to school students. COSAS's main aim was to continue the momentum of the student-led resistance of 1976-1977. According to J Pampallis, COSAS initially had its leanings towards the BC ideology and it was in 1981 that it changed to become more aligned with the Charterist movements. ${ }^{24}$

MS Rakometsi, once part-time History lecturer at UNIQWA, confirms the above, contending that student politics in the 1980s represented the culmination of struggles at three levels, namely learners' education struggles, civic struggles, and national political struggles. ${ }^{25}$ This fresh wave of student politics produced a new generation of student leaders who organised marches and had confrontations with the police. This political mobilisation by COSAS had an influence on the institutions of higher learning, as these members graduated from being high school activists to enrolling at universities and colleges. ${ }^{26}$

SASO was banned in 1977 as part of a national crackdown in the aftermath of the 1976 June student uprising. The Azanian Students Organization (AZASO) was launched in November 1979 to fill the vacuum left by SASO. It brought together the SRCs of the various campuses of black tertiary education institutions. There was a strong alliance between AZASO and the Azanian Peoples' Organisation (AZAPO). The name AZASO was kept with a non-racial approach to student affairs. However, later AZASO moved towards aligning itself with the Charterist organisations. This stance set it on a collision course with AZAPO, which ideologically differed from the Charterists. The organisation later changed its name to the South African National Students Congress (SANSCO), reflecting a complete adherence to the Charterists.

The breakaway of AZASO from AZAPO led to the formation of another student organisation spearheaded by students at Turfloop. This organisation became known as the Azanian Students Movement (AZASM). ${ }^{27}$ On most campuses, the members of AZASM were referred to as amazimuzimu. One of the strong AZASM's rallying points was the issue of boycotting graduation ceremonies at black universities. Furthermore, it promoted the slogan "education for liberation". The organisation issued the following statement that was later

24 J Pampallis, "The establishment and transformation of a repressive system: A historical perspective on educational change in South Africa". In: C Odora Hoppers, B Gustavsson, E Motala and J Pampallis, Democracy and human rights in education and society: Explorations from South Africa and Sweden (Cape Town: HSRC, 2007), p. 27.

25 Rakometsi, p. 270.

26 T Matona, Student organization and political resistance in South Africa: An analysis of the Congress of South African Students, 1979-1985 (BA Honours, University of Cape Town, 1992), p. 1.

27 University of the Witwatersrand, William Cullen Library, Department of Historical Papers, AK 2117-J-2-2-B12-001, "Delmas Treason Trial, 1985-1989: Constitution of the Azanian Students Movement”, p. 2. 
used by the UNIQWA branch with little success, "In actual fact no institution of learning qualifies to be called a university in this country [...] They teach and prepare white students to be bosses and owners of monopoly industries, and black students to be subservient to the white bosses and aspire to white positions at the expense of the black working class [...] Graduation ceremonies in SA cannot be viewed in isolation from the educational system as a whole [...] The Azanian Students Movement notes that: These ethnic and multiracial institutions use these graduation ceremonies as their towering glory to authenticate the myth of separate development; these ethnic and multiracial graduation ceremonies are hunting-grounds for capitalist agents who want to use black students as the lieutenants of oppression and exploitation of the black working class." ${ }^{28} \mathrm{At}$ UNIQWA, amazimuzimu celebrated Steve Biko Day in September without fail and organised stage live performance. The objective, among other, was to keep the memory of Biko alive for recruitment purposes.

On 6 September 1991, SANSCO and the National Union of South African Students (NUSAS) merged to form a non-racial student body called the South African Students Congress (SASCO). The guiding principles of SASCO were democracy, non-racialism, African leadership, and working class leadership. ${ }^{29}$

\section{THE INFLUENCES, STUDENT ACTIVISM AND POLITICAL DIFFERENCES AMONGST STUDENT ORGANISATIONS AT UNIQWA}

This section highlights the influences, student activism and political differences of student organisations as the central thesis of the article. In attempting to explore the above, contrasting experiences/viewpoints of students obtained through the interviews conducted, are highlighted. At face value, the fact that there was a strong political umbilical cord that existed between Turfloop and UNIQWA justified the belief that there were political influences from the former. To a certain extent, this included the exchange of visits by student leaders of the two campuses with a strong political history. I van Kessel describes Turfloop as follows, "The University of the North was commonly known as Turfloop. It played a vital role as a centre of communication, coordination, ideological direction, and recruitment and as a hiding place for activists on the run from the police; thus, it was nicknamed 'Lusaka' in activist and police circles alike." 30

On rare occasions, it was not surprising that Turfloop student leaders would come to Qwaqwa to provide strategic leadership sessions, political and moral support. In its early days, Turfloop was viewed negatively by the

28 University of the Witwatersrand, William Cullen Library, Department of Historical Papers, AK 2117-J-2-2-B12-001, "Delmas Treason Trial, 1985-1989: $8^{\text {th }}$ Anniversary”, p. 7.

29 C Glaser, The ANC Youth League (Athens: Ohio University Press, 2012), pp. 98-101.

30 Van Kessel, p. 96. For more information on Turfloop, see Mawasha, pp. 65-84. 
apartheid government in terms of, what the latter referred to as, the disruptive behaviours of students. The article quoted by $C$ White, which appeared in the Sunday Express of 20 October 1974, provided a clear analysis of how the apartheid regime viewed student political activism at Turfloop. According to the article, Turfloop, from the outset of its existence, exhibited student militancy as SASO's stronghold. Therefore, the article argues that a crackdown from the apartheid regime had to intensify in order to deal with politically active students; thus, the likes of Abram Onkgopotse Tiro were expelled in 1972. ${ }^{31}$

It was only in the mid-1980s that the level of political conscientisation among the UNIQWA students gained momentum. Although reference was made to the 1970s struggle history of Turfloop, UNIQWA students challenged issues that had a direct impact on their academic and political affairs. Student demands were also aligned to the 1980s intensification of the struggle for liberation, especially among the UDF aligned structures in many of the townships. There was also a huge influence and infiltration of the student organisations by the underground structures of the ANC and the Pan Africanist Congress (PAC).

Moeketsi Tladi, who came to UNIQWA after having fulfilled an important political role in his township of Manyatseng in Ladybrand as a political leader, recalls the following about the political influences at UNIQWA, "A certain Mr Sello came to campus. He narrated his story of incarceration to us as the leaders of SASCO that after his release from prison, he was banished to Qwaqwa. He was not supposed to leave the area without permission. He told us that they were given messages by the underground ANC to come and establish the ANC branches because it was clear that the liberation movements were to be unbanned. He established a steering committee at the University to prepare for that. Student leaders from the teacher training colleges around Qwaqwa also joined us. The meetings with Mr Sello ignited politicisation even further." ${ }^{2}$

Another influence was the proximity of the Qwaqwa homeland to the townships of Bohlokong (Bethlehem) and Phomolong (Harrismith). Political activism in these areas had a huge impact on the politicisation of UNIQWA students. Some commuting students from these townships were more exposed to the activities of the Congress-aligned structures outside Qwaqwa and exerted more influence on campus. For example, Sibusiso Sithole, who had played a role during the 16 January 1986 riot in Harrismith, was admitted as a student at UNIQWA in 1987. He remembers that, armed with a deep political background, it was easy for him to contribute to political debates. ${ }^{33}$ Therefore, highly differentiated political influences came from outside of Qwaqwa. This outside

31 C White, From despair to hope: The Turfloop experience, p. 109.

32 TPC. Interview with Mr M Tladi, conducted by M Masooa, Manyatseng Township, Ladybrand, 6 April 2011.

33 TPC. Interview with Mr S Sithole, conducted by C Twala, Intabazwe Township, Harrismith, 16 June 2011. 
influence played a role in dissipating political information among the student organisations. Mokete Pherudi, who came from Maokeng in Kroonstad, recalls, "By the mid-1980s, UNIQWA student population was politically conscientised. There were student organisations affiliated along party lines. There were many reasons to explain this. Some students came to UNIQWA having played significant roles as student leaders at the high school level. Therefore, the influences of COSAS politics were seen again at the University. At the University, we had student organisations, such as SASCO and AZASM that differed practically and ideologically." ${ }^{4}$

Besides the above, one other critical element that led to the politicisation of students at UNIQWA was, to a certain extent, the continuous levels of intransigence of both the Qwaqwa Government and the apartheid regime in addressing the students' academic and political plight. Whenever students campaigned against some university-related issues, the Qwaqwa Police, commonly known as the "Farmer Brown" due to their brown uniforms, supported by white police units from Harrismith and Bethlehem, were unleashed against student activists and those participating alongside.

Also as a strategy to dislodge the students' mobilisation, police would take advantage and conduct midnight random searches of student residences, especially at Lere La Tshepe. Those found with banned material and political pamphlets were arrested, and it often resulted in renewed students uprising/ marches for the release of those arrested..$^{35}$

Without doubt, the above attitude from those in authority of the two governments fermented anger, resentment and aggressive competitiveness amongst the students and, due to their frustrations, they resorted to violence. Ironically, in the midst of challenging the status quo, political differences between student organisations became a reality. Therefore, political misunderstanding and, to a certain extent, intolerance emerged when certain joint campaigns were to be undertaken. Sithole remembers, "Although we rejected political divisions amongst students, the differences emerged repeatedly. Therefore, the main challenge we had was to first overcome ideological and political divisions and be integrated into one main stream of striving for liberation, but that was not easy because of our different approaches. The approaches were highly influenced by political ideologies we held as student organisations. AZASM used slogans such as 'Black Student-Worker Solidarity' or 'Black Worker-Student Solidarity'. There was nothing wrong about such slogans but rallying support under the banner of blackness was questionable." ${ }^{36}$

34 TPC. E-mail correspondence with Dr ML Pherudi, 15 September 2015.

35 Ibid.

36 TPC. Interview with Mr S Sithole, conducted by C Twala, Intabazwe Township, Harrismith, 16 June 2011. 
Political differences, such as the above, compromised the unity that was to be exhibited in the commemoration of important days, such as Sharpeville and June 16. Despite the fact that these days did not appear on the official list of national commemorative days, it was deeply engraved in the consciousness of many South Africans and henceforth commemorated. Rakometsi contends that, "For some, the anniversary of June 16 was a day of mourning and of renewed dedication to firmly-held aspirations and ideals; for others it was a time of apprehension and defensiveness against forces that threatened the existing order; for yet others, a small but increasing radical minority, it was a focal point for the incitement of violence and insurrection." ${ }^{37}$ Most importantly, it was used for recruitment of new members among the first year students.

However, Mashiloane has a different interpretation of the collaboration of the student organisations at UNIQWA. He warns, "Although we campaigned together on some issues, there were deep-rooted ideological as well as political differences between us (SASCO) and AZASM. To be honest, we never trusted each other. For example, we would differ on how to commemorate some of the important days in the liberation struggle. The days, such as Sharpeville, June 16 and Biko's day were commemorated differently. In some cases, we could agree on sharing the same platforms on such days but deliver ideologically different messages. I think that to a certain extent divided the student population even further." ${ }^{38}$

As mentioned previously, at UNIQWA, as in all other black universities at the time, some Afrikaner staff members were politically conservative and they disrespected students in one way or another. Moreover, it remains to be seen as to whether the black academic and non-academic staff were an integral part in supporting the students' political activism. A report compiled by T Reddy of the University of Cape Town (UCT) in 2004 explains that in many of the black universities during the 1970s and 1980s, "the majority of black academics found themselves in the middle between the growing radicalization of students and the watchful eye of the University's management. Besides, they had their own struggles and frustrations as black academics in deeply discriminating university contexts. Some identified with the political demands of the students." ${ }^{39}$

It should be noted that from UNIQWA's point of view, black academics had no strong expressions of university-based activism. However, in the midst of such conditions, in one way or another, some managed to be influential in the student groups. There is evidence, as confirmed by some of the interviewees, that some academics indirectly played a role in conscientising students politically. This was primarily because some of them shared similar political or interest agendas with

$37 \quad$ Rakometsi, p. 242.

38 TPC. Interview with Mr T Mashiloane, conducted by C Twala, Intabazwe Township, Harrismith, 16 June 2011.

39 T Reddy, "Higher Education and social transformation: South Africa case study", Report for the Department of Higher Education and Training, 2004, p. 19. 
the students. In the main, these staff members were influenced by the 1970s and 1980s liberal and Marxist academics who used to engage in debates over the primacy of race or class as the core identity of the liberation struggle.

At UNIQWA some of the political inspiration came from lecturers, such as Sechaba Mahlomaholo. He taught Philosophy of Education. Another one was Benito Khotseng who concentrated more on the History of Education - both were in the Faculty of Education. Accordingly, they complemented each other in terms of the content taught. Tladi recalls that Mahlomaholo and Khotseng emphasised the principle of self-reliance and critical thinking in their teaching. They even prescribed a book about apartheid and education in South Africa by Peter Kallaway. The intention was to make students critical about the injustices of apartheid education. They also advocated for the introduction of more courses on the Qwaqwa campus. ${ }^{40}$ Despite the other challenges experienced, the education content that was presented inspired students to think critically, as it involved courses on critical emancipatory theories and the structure of the apartheid education system. Indirectly, such courses prepared the students for challenges outside the university environment. Largely, this objective was attained.

On the situation at UNIQWA, Mahlomaholo states, "Students at UNIQWA were politically involved. They came mainly from the ANC, BC and Inkatha political persuasions. Many of them after the 1994 elections came to occupy very senior positions in the new democratic SA. In the Free State I can think of Thabo Koaho who became leader of SADTU (teachers' union) and Khotso De Wee who became Director-General of the Free State. I think Chose ka Choeu is still in the NCOP. There are many more but I am citing there three to exemplify the level of political awareness [...] In our lecturing, we infused a lot of the alternative theorisation that talked to the theme of using education as tool for liberation. We were all aware that as a university, we had the responsibility of providing leadership if our country was to be liberated. As students and lecturers, we were heavily involved on the issue of People's Education for People's Power. Just like students, some of us commemorated the Freedom Charter, Sharpeville Day, Steve Biko's Day and advocated for the unbanning of the liberation movements in SA."11

Pherudi's recollection was of Pieter Fourie who taught Biblical Studies. He distributed copies of the Kairos Document (KD) and would encourage his students to read it critically. ${ }^{42}$ To him, the KD offered a different perspective to the interpretation of the Bible and the challenging of the state apparatus

40 TPC. Interview with Mr M Tladi, conducted by M Masooa, Manyatseng Township, Ladybrand, 6 April 2011.

41 TPC. E-mail correspondence with Prof S Mahlomaholo, 29 September 2015.

42 The Kairos Document was a Christian, biblical and theological comment on the political crisis in South Africa during the 1980s. It was a critique of the then theological models which determined the activities the Church engaged in, to try to resolve the political problems of the country. It challenged what it purported as the misuse of the Bible to justify apartheid in South Africa. It was a challenge to the apartheid "State Theology". 
system. ${ }^{43} \mathrm{KD}$ challenged the churches' response to what the authors saw as the vicious policies of the apartheid state under the state emergency declared on 21 July 1985 and evoked strong reactions and furious debates not only in $\mathrm{SA}$, but worldwide. It centred on liberation theology that motivated students to resist the oppressive and repressive apartheid government. On 4 October 1986, he tabled a motion at the Dutch Reformed Church Synod in Cape Town that, "school boycotts be used as a means of peaceful protest to change the present socio-political structure". ${ }^{4}$

These lecturers understood that a university by its very existence should perform not just a single function, but a multiplicity of functions. One such function at the structural level is to provide space for critical dialogues, something that the majority of Afrikaner lecturers never encouraged at UNIQWA. Holding this viewpoint is M Burawoy who says that, "the political consciousness of the institution's members is determined not merely by their roles within the university but by other roles they had held in the past, held in the present or anticipated occupying in the future". ${ }^{45}$ In justification of the above, M Cele opines that the university should create platforms to critically engage in socio-political matters facing the societies. It should afford space for the emergence of radical and militant leaders. ${ }^{46}$ What the likes of Mahlomaholo did was creating platforms for dialogues and debates. To a certain extent, this helped in inculcating a culture of debating issues by the students, thus producing visionary leaders.

Perhaps anticipating political activism at UNIQWA before his assumption of duties as Director/Principal of the institution, Modinger issued a statement that, "This embryonic institution could avoid the history of unrest that has chronically disrupted education at Turfloop. Some students at Turfloop and Fort Hare actually sought confrontation because they preferred to be thrown out before they flunked out." ${ }^{\prime 7}$ With this statement, it was clear that Modinger was not going to tolerate any disruptions by students at the newly established institution. Without doubt, it was these statements that, at later stages, when at the helm of the campus leadership, he found himself in collision with the progressive student organisations that not only challenged his leadership, but also viewed it as anti-progressive. Although the first years after the establishment of UNIQWA were relatively quiet as far as student politics were concerned, this was due to

43 TPC. E-mail correspondence with Dr M Pherudi, 15 September 2015.

44 Moffett, p. 29.

45 M Burawoy, "Consciousness and contradiction: A study of student protest in Zambia", British Journal of Sociology 27(1), March 1976, p. 78.

46 M Cele, "Post-apartheid Higher Education: The role and challenges facing student activists". In: DP Chimanikire (ed.), Youth and Higher Education in Africa: The case of Cameroon, South Africa, Eritrea and Zimbabwe, (Senegal: CODESRIA, 2009), p. 44. Los Angeles: University of California Press, 1982), p. 40. 
the following reasons: Firstly, when the University started in 1985, few students registered. Secondly, there was a heightened level of repression from the apartheid regime on student political activism from the early 1980s. Thirdly, the majority of students who were the first intake were not highly politicised; and fourthly, those who joined from Lefika were in one way or the other indoctrinated as agents of peace and stability from a biblical viewpoint. It was later post1988 that this attitude changed. As mentioned before, the majority of students were teachers studying part-time. Despite the above, students were politically aware, but the ground was not yet sufficiently fertile to start any forceful political mobilisation. In fact, most of them were members of a transitional generation whose early childhood was bound to apartheid and political repression.

From the mid-1980s and mid-1990s, students' actions ranged from marches to sit-ins, hostage-taking, vandalism, pickets, placard demonstrations, boycotts and the disruption of administrative activities when faced with problems. More narrowly, Cele argues that politically minded students, referred to as "disruptive squads", were responsible for this behaviour. ${ }^{48}$ The abovementioned activities provided a yardstick to measure the organisational muscle of student leaders. According to Cele, the change in student activism from direct confrontation to engagement has been widely attributed to the tough positions institutions took during the mid-1990s when student demonstrations were viewed as "not constructive" and to generational factors, such as different aspirations and apathy. He further argues that the change in governance processes and the change in patterns of student activism are related. ${ }^{49}$

Full recognition of the SRC by the UNIQWA management happened towards the end of 1985. September 1985 saw the adoption of a Constitution for the SRC and the election of the first SRC at UNIQWA. Those who constituted the first SRC were: President: KK Mokotjo; Vice-President: SJ Mokoena; Correspondence Secretary: FS Moseme; Minute Secretary: MA Tsukudu; Treasurer: PZ Mlobi; with additional members being: NS Zulu and TA Setai. ${ }^{50}$ Nogwaja Zulu had a different recollection of the involvement as student leaders. As the first SRC, they had to focus on laying out the rules and drafting the Constitution. This was done without the assistance of Turfloop and it differed from the one on the main campus. This was a sign of positive identification as the Qwaqwa Campus of Turfloop. He recalls that they never had any engagement of paying visits to discuss political issues with the SRC on the main campus. According to Zulu, Turfloop students were constantly on strike, whereas there was relative stability at UNIQWA. Nevertheless, the whole SRC supported the mass movement politics of the time without any agenda

\footnotetext{
$48 \quad$ Cele, pp. $37,50$.

49 Ibid., p. 35.

50 Moffett, p. 27.
} 
contrary to that. ${ }^{51}$ Despite these observations by Zulu, the tide changed in the subsequent years.

The most prominent student organisations at UNIQWA during the period under discussion were SASCO and AZASM. AZASM, with its links to the BC, prided itself that the latter was central to the revitalisation of internal student politics in South Africa in the 1970s. It became clear from the above that most of the strains between SASCO and AZASM were based on political, ideological, and tactical disagreements; yet, some were also clearly the result of generational struggle credentials as inherited from the mother bodies. Underestimating the magnitude of political differences within the student organisations, Tladi claims that all organisations' focus was to attain liberation, to fight against inequality in the education system, and to eradicate the homeland system. ${ }^{52}$

According to Mahlomaholo, the main campaigns revolved around the role of education and political liberation of the country. Students used every major political event to create awareness amongst themselves and others that education was political and that true liberation will come through true education. The main slogan they subscribed to was "Education for Liberation" that sharply contrasted with the popular dominant one that advocated for "Liberation Now and Education Later". ${ }^{33}$ The exchange and sharing of students struggles was enhanced when SASCO SRC's created a platform countrywide by inviting each other during the inauguration of the SRC. UNIQWA SRC also participated in such platforms and took best-learned lessons to UNIQWA for adaptation and implementation. ${ }^{54}$

Campaigns by students at UNIQWA were sometimes launched against the Afrikaner lecturers who were often accused of undermining and failing students. Sometimes students would complain that they were accused of being incompetent and not university material. There were also allegations that such lecturers used to have informers from the student population who would usually tip them off when students were about to embark on strikes. Unfortunately, some of these lecturers betrayed their sources by unwittingly revealing their identity because of the language barrier. Some lecturers were accused of being reservists for the South African Defence Force (SADF) who would not come to lectures when deployed to quell riots in the neighbouring townships.

In February 1988, when the new campus of UNIQWA was opened in Blue Gum Bush, students complained about the admission processes. For example, many students, particularly those affiliated to AZASM, alleged that the management of the University was consciously rejecting the re-admission of those belonging to their organisation. They alleged that the management

51 TPC. E-mail correspondence with Prof N Zulu, 21 September 2015.

52 TPC. Interview with Mr Tladi, conducted by M Masooa, Manyatseng Township, Ladybrand, 6 April 2011.

53 TPC. E-mail correspondence with Prof S Mahlomaholo, 29 September 2015.

54 TPC. E-mail correspondence with Dr ML Pherudi, 15 September 2015. 
viewed them as troublemakers. To them, management attempted to weaken their position on campus. AZASM hoped that the move to a bigger campus would assist in the recruitment of new members coming to register at the University for the first time, but that did not realise. However, the University's management denied the above..$^{55}$

In August 1992, the spokesperson on the ANC's Qwaqwa branch, Steve Phohlela, alleged that UNIQWA and other colleges in the area were admitting more students from outside, mostly from Natal, with the aim of reducing the number of ANC supporters. This was considered as a bid to stop ANC activities in the area. According to Phohlela $75 \%$ of the new intake for 1992 at UNIQWA and $60 \%$ at the Tshiya College of Education were from Natal. He indicated that the ANC's lawyers were investigating that. The University's management, as well as the then Qwaqwa Education Minister, Daniel Mokoena, again denied this allegation ${ }^{56}$

One other notable joint campaign happened on Monday, 3 April 1989, when students from UNIQWA, together with those from the teachers training colleges, joined forces and marched to the Qwaqwa government offices to hand over a memorandum demanding that Mopeli ${ }^{57}$ (Qwaqwa Homeland Leader) should not accept "an independent" status from the South African regime. In this regard, Mopeli and his government had long taken a decision not to accept such a status. They argued that, accepting the so-called independence, would mean cutting ties with the rest of South Africa. ${ }^{58}$ Although the Qwaqwa Government had publicly announced the non-acceptance of this so-called independence, students continued to put pressure on the authorities and used this as a rallying point.

Catering for students residing on campus was also a huge challenge for UNIQWA as the service providers could not cope with the basic demands of providing decent meals. In September 1989, students attacked Fedics Company (catering company) and trashed the kitchen. The company was accused of making maximum profit, whilst providing sub-standard meal packages. One other complaint pertained to the working conditions of the workers there. Although this started as a meal issue, it led to the boycott of classes.

With the unbanning of the liberation movements in February 1990 to SASCO and the Charterist organisations, this constituted a huge victory for student politics across the country and at UNIQWA. On the day FW de Klerk announced the pending release of Mandela, the SRC, under the leadership of Morrison Chabane and his deputy, Moeketsi Tladi, organised a mass meeting where the SRC's secretary general, Mokete Pherudi, a final year history student, presented an impromptu lecture of Mandela and the implications of his release to

\footnotetext{
$55 \quad$ Moffett, p. 32.

56 Anon, "Qwaqwa wants to suppress ANC activities", The New Age, 31 July 1992 6 August 1992, p. 18.

57 Hereafter referred to as Mopeli.

58 TPC. Interview with Mr Tladi, conducted by M Masooa, Manyatseng Township, Ladybrand, 6 April 2011.
} 
the country. This event also marked SASCO's celebration of Mandela's release. What was gratifying for them was that a few weeks after Mandela's release from prison, on 25 February 1990, he issued a statement that the ANC was prepared to negotiate with the Qwaqwa homeland government on matters of collaboration. The statement was made after the ANC had just appealed against the court ruling that Botshabelo should not be incorporated into Qwaqwa. ${ }^{59}$ Although students tried to exert pressure on the Qwaqwa Government, the latter had refused such a status from the inception of such talks.

It was almost a pattern at UNIQWA that no academic year passed without disruptions and protests. In 1990, the President of the SRC was Morrison Chabane from (Mokwallo) Vredefort. The Vice-President was Moeketsi Tladi from (Manyatseng) Ladybrand and the Secretary General was Mokete Pherudi from (Maokeng) Kroonstad. All these were SASCO members. On 3 September 1990 students boycotted classes for various reasons, which included the need for an emergency generator to cover the residences, immediate representation of the students on the General Affairs Committee, a review of high fees, and the provision of more computers in the computer laboratory. This was further complicated by the preparations of the Qwaqwa Government to have elections. Ironically, this happened a few months after the unbanning of the liberation movements, such as the ANC and PAC, that were against the homeland governments. UNIQWA students joined forces with the National Education Union of South Africa (NEUSA), COSAS, the National Education, Health and Allied Workers Union (NEHAWU) and SANSCO in order to boycott these elections as they perpetuated apartheid policies. The organisers, led by Isaac Molefe, called for a three-day stay-away to coincide with the elections on 26-29 September. ${ }^{60}$

Cobus Rademeyer, who was a History lecturer at UNIQWA from 1993 to 1999 , recalls, "In some instances, the management of the University tried to accommodate all students' demands, but when the students became too demanding or broke University's property during marches or protests on campus, the management called in the police. This usually led to greater rifts between the management and student leadership, because the students were unhappy with the involvement of the police. During this time (the 1990s), the police were not patient with student protestors and in most instances took immediate action against the students and responded with rubber bullets, teargas and random arrests." ${ }^{61}$

He further states the following about the violent protests, "During one of the protests over low semester marks, the management again called in the police. The students then locked all staff (academic and administration) into

59 For more information on this, see C Twala and L Barnard, "The incorporation of Botshabelo into the former Qwaqwa homeland: A logical consequence of the apartheid system?", Journal for Contemporary History 31(1), June 2006, pp. 162-177.

60 S Makaringe, "Qwaqwa polls slated”, Sowetan, 13 September 1990, p. 11.

61 TPC. E-mail correspondence with Dr J Rademeyer, 29 October 2015. 
the main building on campus. We were called out one by one to come and remove our cars from the parking lot, until only that of the head of security and the head of examinations were left in the parking area. Both their cars were set alight. The students were not hostile to other staff members except those two who were targeted [...] During normal times, one did not really notice any real ties between the two campuses UNIQWA and Turfloop, but the students on the different campuses were supportive of each other when it came to protest actions. In the main, the management at Turfloop was less supportive to the UNIQWA management, leaving the latter solving the problems on its own. I think one contributing factor to this was the geographical distances between the two campuses." 62

In February 1994, students protested again over the issue of the lack of student accommodation. Two new students' residences which had been built failed to accommodate students. Interestingly, the boycotts happened ahead of the national democratic elections that were scheduled for 27 April 1994. The tendency of locking staff members out of campus continued. To calm the situation, the police were called in on several occasions. This time the students demanded the resignation of Modinger, accusing him of unleashing the police to harass them, instead of solving the University's problems. Despite the class boycotts, Modinger never resigned and the classes resumed after the elections of 27 April $1994 .{ }^{63}$ In view of the bad political climate brewing against his leadership, Modinger requested early retirement.

The level of student politics had gone as far as trying to influence the appointment of the Vice-Principal after the Council had granted Modinger's request for early retirement. In August 1995, students disrupted a shortlisting meeting for Modinger's replacement. The students had their preferred candidate, Prof. Moletsane from Lesotho. He was supported by many structures, including the SRC, SASCO, AZASCO and the Pan Africanist Students Organisation (PASO). To the dismay of the above organisations, Moletsane withdrew his candidacy before the process could be finalised. The student organisations alleged that his withdrawal was instigated by some staff members. Despite all the defiant attitudes by the students, another contestant, Prof. OO Dipeolu, from Nigeria, was offered the position. ${ }^{64}$

In October 1995, lecturers, students and workers at UNIQWA denounced the lack of leadership at the campus and called for the suspension of the

62 Ibid.

63 Moffett, p. 46

64 Ibid, pp. 52-54. The era of Dipeolu was characterised by the recruitment drive of African academics from greater parts of the continent and headhunting of former UNIQWA students. His philosophy was that the former UNIQWA students could contribute better to the transformation of the University, as they understood the culture and dynamics of the institution better. That was how later lecturers, such as Mokete Pherudi, Mokena Semela, Mbulelo May and many others, were recruited in 1999. 
three top officials. The call was made at a mass meeting held on Friday, 20 October 1995, where M Kgaphola and T Mthembu made various allegations of mismanagement against the UNIQWA administration. At this meeting, a "motion of no confidence" was passed on the three University officials, namely the VicePrincipal, Deputy-Registrar and Assistant Registrar (Academic).

According to Kgaphola, as quoted by the Sowetan, the problem on the campus started during the first week of October when the outgoing President of the SRC was arrested for public violence, which led to students boycotting classes from 9 October. On 13 October, the academics attended an Academic Forum meeting to discuss the class boycotts and other related campus problems. In that meeting, the academics too passed a "motion of no confidence" in the University's leadership and requested the Council to appoint an independent commission of inquiry to investigate their concerns ${ }^{65}$ Subsequent to this, Kgaphola, Mthembu and A van Zyl were charged with misconduct for bringing the University into disrepute. It was clear from the above that some lecturers, mainly black, understood and supported the students' plight, while another section was frightened and suspicious of what was happening. This interesting mixture of viewpoints at times paralysed management actions.

In February 1996, students started a class boycott that lasted for almost four weeks. The students demanded that the University drop charges against the implicated academics. The University was not prepared to budge on the charges. The Principal, Njabulo Ndebele from Turfloop, had told the students that only the University's Council meeting on 29 March 1996 could drop the charges. ${ }^{66}$ On 11 March 1995, Kgaphola launched an attack on management accusing it of the following irregularities: maladministration, the promotion of under-qualified staff and the employment of family members. Furthermore, he argued that there were racial tensions on campus. He accused Modinger of not taking affirmative action seriously and hampering the process of transformation. In his response, Modinger indicated that he was prepared to step down as the head of the institution but denied the issues of corruption. ${ }^{67}$

The above shows that, in attempts to analyse students' political activism at Turfloop and what later happened in Qwaqwa, there were some elements of similarities, as well as differences, at both campuses. R Morrell observed that the legacy of the students struggle, was not only about the fight against the apartheid system and Bantu Education specifically, but it was also a narrative that inspired anti-authority activities by the youth generally. ${ }^{68}$ Therefore, similar

65 C Keeton, "Call to fire top 3 officials", Sowetan, 23 October 1995, p. 3.

66 W Mbhele, "Rift at Qwaqwa varsity deepens", City Press, 17 March 1996, p. 2.

67 G Collins, "Stalemate grips Turfloop", Sunday Times, 10 March 1996, p. 7.

68 R Morrell, "Do you want to be a father? School-going youth in Durban schools at the turn of the $21^{\text {st }}$ century". In: T Shefer, K Ratele, A Strebel, N Shabalala and R Buikema (eds), 
to the political activities at UNIQWA, aspirations were geared to the liberation of South Africa. Consequently, it was difficult to separate students' grievances on campuses and the "bread and butter" issues at civic levels.

The above clearly shows that student politics and protests at UNIQWA reflected a mixture of violent and non-violent activities. However, students and the organisations they supported rarely used violent or non-violent protest to the complete exclusion of one another. Theoretically, this could be explained in two ways, namely, that generally protest is a strategy that organisations choose instrumentally in interaction with the adversary from which they seek concessions. According to this view, exclusion of certain groups or issues from conventional processes of decision-making pushes people to disrupt the system through dissent. Others embrace violence on the rationale that only stiff costs can compel those in authority to make speedy concessions.

\section{CONCLUSION}

As in many other areas around the country where student organisations existed, at UNIQWA dominant organisations were at the forefront in fighting for political power. Therefore, the situation resulted in the contestation for control of political space by the ideologically different student organisations. These organisations also undermined each other. SASCO viewed AZASM as a lesser vocal student organisation that played the racism card and was opportunistic in student matters.

The article shows how important student activism was in helping to form the political identity of youth-aged populations during the period under discussion and in later years. This became essential, because universities, by nature, often have the resources and networks to inspire political consciousness and social change.

From boys to men: Social constructions of masculinity in contemporary society (Cape Town: UCT Press, 2007), p.76. 